\title{
WANITA TUNA SUSILA DI SUMATERA BARAT DAN PEMBINAANNYA (STUDI KASUS PANTI ANDAM DEWI SOLOK)
}

\author{
Doni Nofra \\ LAIN Bukittinggi,doninofra25@gmail.com \\ Inggria Kharisma \\ IAIN Bukittinggi, inggriakharisma@gmail.com
}

Diterima: 12 Januari 2019

Direvisi : 23 Maret 2019

Diterbitkan: 30 Juni 2019

\begin{abstract}
Tuna Susila (WTS) women are women who sell themselves and perform sexual acts as a livelihood, in terms of religion and health, the actions of Tuna Susila (WTS) women violate the norms in living life. In overcoming their efforts, there needs to be a guidance for Women Tuna Susila (WTS) to change their mindset so that they leave acts that are not following the prevailing norms in life. They can find better jobs and develop the knowledge that is in themselves as well as the knowledge that has been given while in the institution and return to the right path. The theory used in this study is the social theory of phenomenology (phenomenology Sociology), which was put forward by Alfred Schuts, who states that buman action becomes a social relationship if humans give meaning or meaning to their activities as something meaningful. This study uses qualitative methods with descriptive types to develop the problems to be studied. From the results of the study, it was concluded that the coaching process that was obtained by Women Tuna Susil (WTS) while in the Andam Dewi Solok orphanage, had made most of the Tuna Susil Women (WTS) leave their jobs as Tuna Susil (WTS) and could continue their lives towards better. Forms of guidance given to Women with Tuna Susil (WTS) at Andam Dewi Solok orphanage can be grouped into four of them: (a). Physical guidance aims to improve the physical and health conditions of Tuna Susila Women (WTS) to be able to absorb the guidance material delivered. (b). Thoughtful guidance, the aim is to guide and improve the mental or psychological of the client. (c). Community social guidance aims to lead to harmony and community life togetherness. (d). Skills guidance, the purpose of this skill is for those who are trained to gain knowledge and skills so they can open their own business from the skills they have.
\end{abstract}

Keywords: Religious Coaching, Prostitute, House of Andam Dewi Solok.

\begin{abstract}
Abstrak
Wanita Tuna Susila (WTS) adalah wanita yang menjual diri serta melakukan perbuatanperbuatan seksual sebagai matapencaharian, dilihat dari segi agama dan kesehatan, perbuatan Wanita Tuna Susila (WTS) melanggar norma-norma dalam menjalani kehidupan. Dalam mengatasi perbuatan mereka tersebut perlu ada pembinaan bagi Wanita Tuna Susila (WTS) untuk merubah pola pikir mereka agar meninggalkan perbuatan yang tidak sesuai dengan norma yang berlaku dalam kehidupan. Mereka bisa mencari pekerjaan yang lebih baik dan mengembangkan ilmu-ilmu yang ada di dalam dirinya begitu juga dengan ilmu yang telah di berikan selama berada di panti, dan kembali kejalan yang benar. Teori yang digunakan dalam penelitian ini adalah teori sosial yaitu fenomenologi (fenomenological Sociology), yang dikemukakan oleh Alfred Schutz yang menyatakan tindakan manusia menjadi suatu hubungan sosial bila manusia memberi arti atau makna tertentu terhadap tindakannya itu sebagai sesuatu yang penuh arti. Penelitian ini menggunakan metode kualitatif dengan tipe deskriptif untuk mengembangkan permasalahan yang akan diteliti. Dari hasil penelitian diperoleh kesimpulan bahwa proses pembinaan yang di dapatkan oleh Wanita Tuna Susil (WTS) selama berada di panti Andam Dewi Solok, telah membuat sebahagian besar Wanita Tuna Susil (WTS) meninggalkan pekerjaannya sebagai Wanita Tuna Susil (WTS) dan bisa melanjutkan kehidupan kearah yang lebih baik. Bentuk pembinaan yang diberikan kepada Wanita Tuna Susil (WTS) di panti Andam Dewi Solok dapat dikelompokkan menjadi empat diantaranya: (a). Bimbingan fisik, bertujuan untuk meningkatkan fisik dan kondisi kesehatan Wanita Tuna Susila (W'TS) agar mampu menyerap materi pembinaan yang disampaikan. (b). Bimbingan mental, tujuannya adalah utuk membimbing dan memperbaiki mental atau psikologis para kelayan. (c). Bimbingan sosial kemasyarakatan, bertujuan untuk mengarahkan
\end{abstract}


kepada tata kerukunan dan kebersamaan hidup bermayarakat. (d). Bimbingan keterampilan, tujuan keterampilan ini agar mereka yang dibina memperoleh pengetahuan dan keterampilan sehingga dapat membuka usaha sendiri dari keterampilan yang dimilikinya.

Kata Kunci: Pembinaan Keagamaan, Wanita Tuna Susila, Panti Andam Dewi Solok.

\section{PENDAHULUAN}

Menurut Bonger, yang dikutip dalam buku Kartini Kartono, bahwa Wanita Tuna Susila (WTS) adalah wanita yang menjual diri serta melakukan perbuatan-perbuatan seksual sebagai matapencaharian. ${ }^{1} \quad$ Kemudian dorongan seseorang manusia menjadi PSK ini terdapat dua unsur di antaranya yaitu unsur ekonomis (prostitutie) dan unsur mata pencaharian (beroepsmating). ${ }^{2}$ Dalam hal ini dinyatakan adanya unsur-unsur ekonomi yang menyebabkan seorang wanita menjadi Wanita Tuna Susila (WTS). ${ }^{3}$ Sedangkan Wanita Tuna Susila (WTS) selalu dikecam dan diabaikan dalam masyarakat karena Wanita Tuna Susila (WTS) sebagai masyarakat yang merusak moral dan pekerjaannya pekerjaan yang tidak mulia, Masyarakat yang sering bergaul dengan Wanita Tuna Susila (WTS) juga dipandang sebelah mata, kemudian laki-laki piaraan atau kekasih Wanita Tuna Susila (WTS) dianggap sebagai penjahat professional dan berbahaya. ${ }^{4}$

Keberadaan Wanita Tuna Susila (WTS) menimbulkan berbagai masalah dalam masyarakat, diantaranya dapat menimbulkan penyakit berbahaya dan menyebar luaskan penyakit kelamin dan kulit. Yaitu virus yang memperlemah kekebalan pada tubuh manusia yang sering disebut Human Immunodeficiency Virus (HIV) dan Acquired Immune Deficiency

\footnotetext{
1 Kartono Kartini, Patologi Sosial. (Bandung: CV Rajawali, 2011), 213.

${ }^{2}$ Widya Suci Ramadhani, Sri Sulastri, And Soni Akhmad Nurhaqim, "Proses Rehabilitasi Sosial Wanita Tuna Susila Di Balai Rehabilitasi Sosial Karya Wanita (Brskw) Palimanan Kabupaten Cirebon," Prosiding Penelitian Dan Pengabdian Kepada Masyarakat 4, No. 2 (July 31, Https:/ /Doi.Org/10.24198/Jppm.V4i2.14292. 2017),

${ }^{3}$ Kartono Kartini, Patologi..., 213

4 Simandjuntak, Pengantar Kriminal dan Patologi Sosial, (Bandung: Tarsito, 1977), 282.
}

Syndrome (AIDS), merusak sendi-sendi kehidupan keluarga karena suami-suami yang tergoda oleh Wanita Tuna Susila (WTS) biasanya melupakan fungsinya sebagai kepala keluarga sehingga rumah tangganya menjadi berantakan, memberikan pengaruh kepada lingkungan, khususnya anak-anak muda, remaja pada masa puber. ${ }^{5}$

Di sisi lain, Wanita Tuna Susila (WTS) tidak diterima oleh masyarakat hal ini disebapkan Wanita Tuna Susila (W'TS) dianggap sebagai pekerjaan yang tidak mulia dan memalukan. Wanita Tuna Susila (WTS) juga dianggap sampah dalam masyarakat, oleh karena itu pemerintah berusaha untukmengatasi masalah pelacuran ini dalam masyarakat, supaya masyarakat bertindak dan bertingkah laku sesuai dengan aturan-aturan dan norma-norma yang berlaku dalam masyarakat. ${ }^{6}$

Menyikapi masalah Wanita Tuna Susila (WTS) di Sumatera Barat, perlu penanganan secara kontiniu, terpadu atau berkesinambungan dengan melibatkan berbagai disiplin ilmu dan profesi, seperti pekerjaan sosial, dokter, psikolog, guru agama, mubaligh, serta profesi lainnya. Selain itu, adanya kerjasama antar lembaga terkait baik

${ }^{5}$ Kartono Kartini, Parologi..., 249.
${ }^{6}$ Yuda Setia Laksana, Sholih Sholih, and Mochamad Naim, "Pelatihan Tata Rias Pengantin Bagi Wanita Tuna Susila Dalam Meningkatkan Kemandirian Usaha," Journal of Nonformal Education and Community Empowerment 1, no. 1 (June 30, 2017): 43-54, https://doi.org/10.15294/pls.v1i1.14794.

7 Alfurqan Alfurqan, Rini Rahman, and Muhamad Rezi, "Pendidikan Orang Dewasa Yang Dikembangkan Rasulullah," Islam Transformatif: Journal of Islamic Studies 1, no. 1 (August 7, 2017): 15-29, https://doi.org/10.30983/IT.V1I1.327. 
pemerintah maupun swasta, serta keterlibatan dan peran nyata organisasi sosial masyarakat. ${ }^{8}$

Untuk mengatasi masalah pelacuran atau Wanita Tuna Susila (WTS) di Sumatera Barat, pemerintah mendirikan sebuah panti sosial yang disebut Andam Dewi yang terletak di Solok. Berdasarkan hasil wawancara dengan salah seorang pengurus panti Andam Dewi Solok, (Sabhana) panti ini didirikan pada tahun 1979, dan beroperasi tahun 1980. Visinya agar terwujudnya suatu lembaga pelayanan sosial yang representativ dan kondusif guna terselenggaranya pelayanan dan rehabilitasi social Wanita Tuna Susila (WTS).

Misi panti Adam Dewi Solok yaitu

a. Melaksanakan Pelayanan dan Rehabilitasi Wanita Tuna Susila (WTS) sesuai dengan panduan yang telah ada.

b. Meningkatkan mutu sumber daya manusia dengan penyelenggaraan pelayanan dan rehabilitasi sosial.

c. Meningkatkan sarana dan prasarana pelayanan dan rehabilitasi sosial.

d. Meningkatkan program dan kegiatan pelayanan dan rehabilitasi sosial.

e. Meningkatkan program dan kegiatan pembinaan mental keagamaan, keterampilan dan bimbingan sosial Wanita Tuna Susila (WTS). ${ }^{10}$

Berdasarkan fenomena yang telah dijelaskan di atas, perlu rasanya untuk melakukan pengabdian berkaitan dengan pembinaan kreatifitas terhadap warga binaan panti Andam Dewi Solok tersebut.

Panti sosial Andam Dewi terletak di Kayu Aro Kabupaten Solok. Lokasi panti sosial Andam Dewi ini dikatakan strategis dikarenakan letaknya berada di pinggir Kota Solok yaitu berada di kawasan kantor Bupati Solok yang kondisinya sangat jauh dari keramaian, sehingga memadai untuk

8 Sabhana (Pembina Panti Andam Dewi Solok), Wawancara, Solok, tgl. 13-08-2018.

${ }^{9}$ AD/ART Panti Andam Dewi Solok, 1980

${ }^{10} \mathrm{Ibid}$. pelaksanaan rehabilitasi sosial bagi para Wanita Tuna Sosial.

Lokasi panti sosial Andam Dewi Solok mudah ditemukan karena lokasinnya berada pada kawasan Kantor Bupati Solok atau dikawasan wisata Kayu Aro (tugu ayam) yang bisa dibilang cukup tenang karena jauh dari keramaian. Kondisi eksternal yang demikian cukup kondusif untuk pelaksanaan program dari panti sosial Andam Dewi Solok yang memang membutuhkan ketenangan. Begitu pula halnya dengan lingkungan internalnnya yang luas dan kebersihannya terjaga ini juga mendukung kenyamanan warga binaan pada saat mengikuti kegiatan di panti sosial Andam Dewi Solok. ${ }^{11}$

Bentuk bangunan wisma dan kelas yang kokoh membuat para klien atau Wanita Tuna Susila (WTS) merasa nyaman untuk mengikuti kegitan di panti sosial Andam Dewi. sarana dan prasana yang tersedia di panti saat ini sudah memadai sehingga hal ini mendukung kelancaran kegiatan rehabilitasi dan pelatihan kerja yang ada di panti sosial Andam Dewi Solok semakin lebih baik.

\section{PELAKSANAAN}

Jangka Waktu pelaksanaan kegiatan pelayanan dan rehabilitasi sosial di Andam Dewi Solok, secara regular adalah selama 6 (enam) bulan, dan ada juga yang sampai 2 (dua) tahun. Pelaksanaan kegiatan rehabilitasi memiliki sasaran wanita yang akan menjadi klien. Sasarannya yaitu wanita usia 17-40 tahun dengan kondisi pribadi dan lingkungan mengalami diharmonisasi sosial, penyimpangan norma sehingga Wanita Tuna Sosial dan gangguan psikologis. ${ }^{12}$ Berikut sasaran warga binaan Andam Dewi Solok;

Sasaran utamanya adalah Wanita tuna susila (WTS) dan Wanita Korban Traficking yang dipaksa menjadi pelacur.

\footnotetext{
${ }^{11}$ Sabhana, Wawancara, Solok, tgl 13-08-2018.
}

12 AD/ART Panti Andam Dewi Solok, 1980. 
Sasaran Penunjangnya adalah; Keluarga Kelayan atau siswa; Tokoh masyarakat; LSM/ Orsos/Instansi Pengirim; Germo atau mucikari; dan Perantara atau broker.

\section{GAMBARAN WANITA TUNA SUSILA (WTS) YANG DIBINA DI PANTI ANDAM DEWI SOLOK}

Pengabdian yang dilakukan ini menggunakan teknik wawancara untuk mendapatkan data penelitian yang dibutuhkan dari informan. Pengabdi mewawancara informan Wanita Tuna Susila (WTS) sebagai narasumber dari pengabdian ini. Sedangkan untuk informan pendukung, peneliti menggunakanmateri bimbingan, dan materi dalam pelatihan kerja bagi klien di Andam Dewi Solok.

\section{Gambaran responden penelitian sebagai berikut:}

1. Inisial DS

Informan yang pertama dalam pengabdian ini adalah Saudari DS yang berusia 35 tahun. Saudari ini merupakan penghuni di Andam Dewi Solok yang berasal dari Kota Padang, tetapi tertangkap melalui jaringan Satpol PP di Pasaman Simpang Empat. Pendikan terakhir Saudari DS adalah tamatan SMA. Setelah pengabdi melakukan pendekatan dan mewawancarainya, banyak hal yang disampaikannya berkaitan dengan terjerumusnya ke dalam Wanita Tuna Susila (WTS).

DS menyampaikan melalui wawancara dengan pengabdi dia menjadi WTS karena faktor ekonomi yang tidak mampu dia atasi. Masuknya DS ke dalam Kehidupan Wanita Tuna Susila (WTS) berawal dari suaminya yang pergi tampa kabar dan sudah menikah lagi dengan wanita lain. Tuntutan ekonomi yang begitu berat yaitu, saya mesti menghidupkan 3 orang anak saya dan juga uang sekolahnya.
Awalnya saya mencoba bekerja dengan orang lain, tapi tidak cukup untuk biaya kehidupan keluarga saya.

Pada tahun 2015 saya mencoba bekerja di luar Kota Padang dan berangkat ke Pasaman Simpang Empat, disana saya bekerja disebuah PT yang pekerjaannya memasak untuk pekerja PT tersebut. Awalnya saya lakukan dengan baik, namun banyak juga rayuan dari orang-orang yang bekerja disana untuk menambah uang belanja, akhirnya saya pun mulai mencobacobanya. Awalnya saya hanya melayani satu orang saja tampa diketahui oleh orang lain. Namun setelah dijalani godaan semangkin banyak, akhirnya saya mencoba dengan yang lain. Inilah awal dari dunia Wanita Tuna Susila (WTS) saya, ungkapan DS ketika diwawancara di Andam Dewi Solok.

Menjadi Wanita Tuna Susila (WTS) ini sudah saya lakukan lebih kurang 3 tahun untuk memenuhi kebutuhan 3 orang anak saya, saya tau pekerjaan ini tidak baik namun harus bagaimana lagi, saya tidak bisa mencukupi kebutuhan keluarga saya kalau bekerja yang lain. Kalau masalah penghasilan, biasanya dari tanggal 1 sampai 15 awal bulan saya mendapatkan rata-rata Rp. 600.000,- satu hari degan orang yang berganti-ganti. Kalau di atas tanggal 15 biasanya saya mendapatkan rata-rata $\mathrm{Rp}$. 250.000,- sampai 300.000,- setiap harinya. Dengan penghasilan yang lumayan besar inilah saya merasa nyaman bekerja menjadi Wanita Tuna Susila (W'TS), saya bekerja tidak terlalu susah uangnya lumayan banyak. Saya masuk panti Andam Dewi Solok karena tertangkap disebuah penginapan dengan lelaki oleh Satpol PP dua bulan yang lalu. ${ }^{13}$

\section{Inisial NA}

${ }^{13}$ DS, Wawancara, Solok, Senin 26 November 
Pergaulan merupakan suatu hal penting untuk diperhatikan dalam kehidupan sehari-hari. Sesuai dengan hasil wawancara dengan salah seorang Wanita Tuna Susila (WTS) yang bernama NA, yang biasa dipanggil Mona. Mona yang berasal dari Kota Padang, tertangkap oleh Satpol PP tujuh bulan yang lalu di sebuah Hotel.

Menurut keterangannya, awal saya melakukan pekerjaan sebagai Wanita Tuna Susila (WTS) karena suka berhuru-hara bersama teman-teman, ada salah satu teman yang menawarkan pekerjaan tersebut dengan mengambarkan pendapatan yang bayak setiap malamnya. Hal lain yang melarbelakangi saya bekerja sebagai Wanita Tuna Susila (WTS) karna sebelumnya saya pernah menikah di bawah tangan, namun suami saya tidak bertangung jawab.

Awal ditawarkan, saya menolak karena masih memikirkan orang tua. Tetapi teman saya terus mengajak dan merayu sehinga saya terpedaya. Saya tidak melayani semua tamu, tapi saya hanya memilih tamu yang saya suka. Karena saya pernah mendapatkan ancaman jadi saya hanya pasrah. Melalui wawancara di pandi Andam Dewi Solok, penghasilan yang didapatkan oleh M tidak menentu, karena bayaran tergantung kepada tamu (sesuai dengan pekerjaan) yang penting bayaran paling bawah sebesar Rp. 100.000,- ${ }^{14}$

3. Inisial AN

Setelah menikah setiap pasangan pasti menginginkan keluarga yang bahagia. Tetapi yang terjadi pada AN salah seorang warga yang berada di panti Andam Dewi Solok mengalami kegagalan dalam rumah tangga. Menurut wawancara yang dilakukan di panti Andam Dewi, latar belakang AN masuk ke panti karena dihantarkan oleh suami ke panti Andan Dewi. Penyebab dihantarkan oleh suami tidak tau pasti

${ }^{14}$ NA, Wawancara, Senin 26 November 2018. entah karna ekonomi atau tidak bisa menerima istrinya. Merurut pengakuannya, Andini saat ini sedang hamil. ${ }^{15}$

\section{Inisial WT}

WT adalah salah satu Wanita Tuna Susila (WTS) yang berasal dari Pasaman Timur. Penyebab WT masuk ke panti Andam Dewi karena melakukan LGBT. WT tertangkap oleh Satpol PP dan diserahkan ke Panti. Latar belakang WT sebagai pelaku LGBT karena terpengaruh oleh pergaulan bebas yang sangat sulit dikontrolnya. Melalui wawancara dengan WT, dia juga kurang perhatian dari kelurga terutama orang tua. Oleh karena itu, dia sering bergaul dengan teman yang mengakibatkan saling suka dan terjerumus ke dalam jalan yang salah. ${ }^{16}$

5. Inisial NK

Panti Adam Dewi Solok merupakan tempat pendidikan Wanita Tuna Susila (WTS) yang menampung dari berbagai daerah di Sumatera Bara., Salah satu Wanita Tuna Susila (WTS) yang tertangkap ialah bernama NK, dia tertangkap di Padang, namun alamat aslinya adalah Solok. Menurut wawancara di panti Andam Dewi, latar belakang NK menjadi Wanita Tuna Susila (WTS) karna masalah dalam keluarga dan ekonomi. Menurut keterangannya, awalnya saya sudah menikah dua kali, namun setiap pernikahan saya gagal. Karena kurangnya kebutuhan hidup makanya ia mencoba bekerja sebagai Wanita Tuna Susila (WTS) dan pendapatan yang didapat setiap malamnya lumanyan besar. NK sudah hampir 10 bulan berada di panti Andam Dewi Solok. ${ }^{17}$

6. Inisial AS

AS adalah seorang Wanita Tuna Susila (WTS) yang mempunyai tiga orang anak. Dia memilih pekerjaan Wanita Tuna

\footnotetext{
15 ARN, Wawancara, Senin 26 November 2018. ${ }^{16}$ WT, Wawancara, Senin 26 November 2018.

${ }^{17}$ NK, Wawancara, Senin 26 November 2018.
} 
Susila (WTS) karena tuntukan biaya kehidupan sehari-harinya. Dia telah ditinggalkan oleh suaminya dan harus memenuhi kebutuhan ketiga anaknya. Karena ekonomi jadi ia memilih pekerjaan tersebut dan tertangkap oleh Satpol PPL. Ibuk tersebut berasal dari Kota Padang. Kondisi ibuk AS pada saat sekarang ini di panti Andam Dewi Solok adalah terkena gangguan psikologis dan sangat susah di ajak komunikasi. ${ }^{18}$

7. Inisial PD

PD merupakan salah seorang Wanita Tuna Susila (WTS) di panti Adam Dewi yang berasal dari Pariaman. Menurut wawancara, latar belakang dia menjadi Wanita Tuna Susila (WTS) karena permasalahan keluaga serta ekonomi. Menurut keterangannya, saya dimasukkan oleh salah seorang keluarga yang bekerja di panti Andam Dewi Solok, karena keluarga saya merasa kasihan dengan keadaan orang tua saya yang sering bertengkar dan tidak memperhatikan saya. Selain kurang kasih sayang dari orang tua ekonomi saya juga kurang cukupi. Oleh karena itu saya di bawa oleh keluarga dan dititipkan di panti Andam Dewi Solok. ${ }^{19}$

8. Inisial PA

Salah seorang Wanita Tuna Susila (WTS) yang terlibat dalam jaringan Wanita Tuna Susila (WTS) adalah PA yang berasal dari Jawa Tengah. PA tertangkap di salah satu Hotel di Padang oleh Satpol PP yang sedang razia an diserahkan ke panti Andam Dewi. Menurut keterangannya, saya melakukan pekerjaan tersebut karena pengaruh pergaulan bebas. Selain itu tergoda oleh pendapatan yang lumayan banyak setiap malamnya. Saya mendapatkan penghasilan yang paling bnyak dalam satu malam mencapai 800.000 sedangkan yang

18 AS, Wawancara, Senin 26 November 2018.

19 PD, Wawancara, Senin 26 November 2018. paling sedikit sekitar 100.000 tergantung kepada tamu dan jumlah tamu yang dilayani tersebu. ${ }^{20}$

9. Inisial HY

HY terlibat dalam pergaulan bebas yaitu suka sesama jenis (LGBT) yang berasal dari Dumai. Dia terkena razia Satpol PP karena sedang berhubungan dengan sesama jenis dan diserahkan ke panti Andam Dewi Solok bersama dengan pasangannya, namun di sana petugas membedakan wismanya. Menurut keterangannya, HY pernah menjalin hubungan dengan laki-laki, namun dia disakiti dan merasa trauma dan tidak percaya sama sekali kepada lelaki. Akibat faktor tersebut dia mulai menyukai sesama jenis dan terlibat dalam jaringan LGBT. ${ }^{21}$

10.Inisial AN

AN adalah seorang Wanita Tuna Susila (WTS) yang hanya menjalankan kehidupan selama satu bulan di panti Andam Dewi Solok. Menurut keterangannya, saya masuk ke panti Andam Dewi, karena ditanggap oleh Satpol PP pada saat berenti di salah satu PO Wanita Tuna Susila (WTS) di karenakan hujan. Saya tidak tau apa-apa dan saya tidak pernah melakukan pergaulan bebas, hanya saja saya tidak mengetahui tempat tersebut. Oleh karena itu saya di bawa dan di masukkan ke panti Andam Dewi. Setelah diperiksa ternyata saya terbukti tidak bersalah, dan saya akan di kelurkan dalam beberapa hari kedepannya. ${ }^{22}$

11.Inisial MY

Ekonomi merupakan hal yang sangat penting dalam kehidupan, ekonomi bisa menjerumuskan manusia kedalam halhal yang tidak baik. Sama halnya seperti salah seorang Wanita Tuna Susila (WTS) yang bernama MY. Dia adalah salah

\footnotetext{
${ }^{20}$ PA, Wawancara, Senin 26 November 2018.

${ }^{21} \mathrm{HY}$, Wawancara, Senin 26 November 2018.

22 AN, Wawancara, Senin 26 November 2018.
} 
seorang yang terlibat dalam pergaulan bebas. Menurut wawancara, karena faktor ekonomi saya mencoba-coba untuk melakukan pekerjaan tersebut, saya ditawarkan oleh teman dan mengambarkan mendapatkan uang yang banyak. Berawal dari coba-coba saya merasa kecanduan karna sangat mudah mencari uang dengan hal tersebut dan sampai akhirnya saya tertangkap oleh razia gabungan Satpol PP di salah satu hotel. ${ }^{23}$

\section{PROSES PELAYANAN DAN REHABILITASI SOSIAL DI PANTI ANDAM DEWI SOLOK}

Berdasarkan sumber data yang didapatkan dari dokumentasi di Panti Sosial Karya Wanita (PSKW) Andam Dewi Solok ada beberapa tahapan pelayanan rehabilitasi di panti Andam Dewi Solok seperti yang di paparkan oleh Desi salah satu Wanita Tuna Susila (WTS) yang dibina di panti yaitu:

Di panti Andam Dewi Solok ini ada proses rehabilitasi sosial, rehabilitasi sosial ini merupakan suatu yang tidak boleh ditinggalkan juga tidak bisa dipisahkan dari pembinaan yang akan dilakukan di panti ini. Jadi yang pertama itu ada yang dimanakan dengan pendekatan awal, pendekatan awal itu suatu kegiatan yang berada di luar lingkungan, nanti kita di sana ada proses identifikasi, motifasi dan ada seleksi, nah itu untuk pendekatan awalnya.

Tahapan proses rehabilitasi di Andam Dewi Solok ada 3 tahapan utama, pendekatan awal, penerimaan WTS, dan tahap rehabilitasi.

Pendekatan Awal, terdiri dari; Orientasi dan Konsultasi; Identifikasi; Motivasi; dan Seleksi.

Penerimaan Wanita Tuna susila (WTS) dengan prosedur; Registrasi; Penelaahan dan Pengungkapan masalah (Assesment); dan Penempatan kelayan pada program.

\footnotetext{
${ }^{23}$ MY, Wawancara, Senin 26 November 2018.
}

Setelah penerimaan, maka dilakukan tahap Rehablitasi. Berdasarkan informasi dari salah satu Wanita Tuna Susila (WTS), kegiatan yang dilakukan di dalam panti yang utama adalah tahapan rehabilitasi. Tahapan ini mencakup beberapa kegiatan inti seperti bimbingan fisik, mental dan sosial, keagamaan serta bimbingan keterampilan.

Tahap bimbingan fisik, mental, keagamaan dan sosial sendiri terdiri dari berbagai macam bimbingan. Bimbingan fisik seperti pemeliharaan kesehatan, olahraga, dan sarana kebersihan, pemenuhan kebutuhan dasar Wanita Tuna Susila (WTS) seperti sandang, pangan dan tempat tinggal di asrama. Bimbingan mental meliputi bimbingan keagamaan, kedisiplinan, budi pekerti, kesehatan mental terapi individu dan lain-lain seperti yang pengabdi tuliskan di atas. Sedangkan untuk tahapan bimbingan sosial meliputi bimbingan kewirausahaan, bahasa, seni budaya, muatan lokal, dan pendampingan asrama.

Tahapan bimbingan fisik, mental, dan sosial diharapkan mampu menumbuhkan atau memperbaiki mental, fisik serta sosial yang kuat bagi para klien sehingga ketika mereka kembali kemasyarakat, mereka bisa diterima dan mandiri. Bimbingan keagamaan, budi pekerti, dan kedisiplinan diutamakan sebagai dasar pembentukan kepribadian para klien agar menjadi manusia yang lebih baik dan berakhlak. Ditambah dengan adanya bimbingan sosial yang berfungsi untuk memberilkan pembelajaran serta pemahaman tentang pentingnya hidup bermasyarakat dan bekerjama dengan orang lain di masyarakat.

Tahap bimbingan keterampilan seperti menjahit, bordir, memasak, kerajinan tangan, tata rias, salon, olah pangan, serta batik, diharapkan mampu memberikan bekal keterampilan bagi para klien untuk mandiri dan mampu hidup lebih baik di masyarakat. Kegiatan di panti Andam Dewi Solok 
dilakukan secara rutin sesuai dengan jadwal yang sudah ditentukan.

GAMBARAN PEMBINAAN WANITA TUNA SUSILA (WTS) DI PANTI ANDAM DEWI SOLOK

Pembinaan yang dilakukan di panti Andam Dewi Solok kepada Wanita Tuna Susila (WTS) meliputi berbagai bentuk pembinaan, baik secara berkelompok maupun secara pribadi, di bawa ini penulis akan mencoba menguraikan bagaimana bentuk kegiatan pembinaan yang dilakukan di panti Andam Dewi Solok. Dalam berbagai pembinaan yang diberikan kepada Wanita Tuna Susila (WTS) Andam Dewi Solok, pada kali ini, memfokuskan kepada kreatifitas atau bimbingan dalam bidang usaha, topik ini diambil karena mengingat para Wanita Tuna Susila (WTS) yang dibina di panti secara umum berawal dari kehidupan ekonomi.

Syabhana selaku kepala panti dan Mawardi pembina di panti juga menyampaikan agar tim pengabdi bisa mendatangkan orangorang yang ahli dari bidang usaha dan ekonomi sehingga bisa membagikan ilmunya kepada Wanita Tuna Susila (WTS) yang dibina di panti ini. Kami meminta orang yang ahli karena selama ini kami hanya mengandalkan keahlian yang ada di panti ini saja, harapan kami agar Wanita Tuna Susila (WTS) yang keluar dari panti ini nantinya tidak lagi kembali kepada pekerjaannya sebagai PSK, tapi mereka sibuk dengan usaha yang mereka tekuni melalui pembinaan yang kita berikan di panti ini. $^{24}$

\section{Bimbingan Fisik}

Kegiatan yang dilakukan dalam
bimbingan fisik ini bertujuan untuk
meningkatkan fisik dan kondisi kesehatan
Wanita Tuna Susila (WTS) agar mampu
menyerap materi pembinaan yang

${ }^{24}$ Sabhana, Wawancara, Senin 13 Agustus 2018. disampaikan. Bimbingan ini dilakukan mengingat kondisi atau kesehatan Wanita Tuna Susila (WTS) saat datang atau masukan ke panti dalam keadaan tidak sehat. Untuk membangkitkan semangat mereka kembali maka diperlukan bimbingan fisik agar mereka tidak muda pata semangat dalam pembinaan nantinya. ${ }^{25}$

"Saat pertama kali mereka datang, mereka terkesan jorok, tidak sopan, tidak punya etika, pakaian senono, make up tebal, genit dan pemarah. Selama kurang lebih sebulan mereka memberontak tinggal di panti, mungkin karena terbiasa hidup bebas dan tidak diatur-atur, sukanya marahmarah, maki-maki petugas. Kesehatan mereka cukup buruk, mungkin waktu di jalan tidak dirasa tapi setelah masuk panti baru ketahuan kalau mereka menderita penyakit."26

"Benar, waktu mereka pertama kali kesini, mereka tidak sopan, etika kurang, tidak memiliki rasa malu, terkesan genit. Ada yang marah-marah, maki-maki, petugas panti. Kesehatan mereka kurang baik.",27

"Setiap minggu sekali, saya dan tementemen dikunjungi oleh orang kesehatan Solok. Untuk memeriksa darah, tensi WTS, kalau ada yang sakit biasanya langsung dikasih obat. Atau W'TS yang kami bina di bawa ke Puskesmas." 28

"Waktu di Panti, saya dapat bimbingan fisik seperti olah raga, pemeriksaan kesehatan, penyuluhan dari petugas kesehatan. Manfaat yang saya rasakan bayak, kondisi saya selama di sana baik, saya jarang sakit, soalnya makannya teratur dan bergizi. Apalagi setiap minggunya diperiksa oleh tim kesehatan. Jadi kalau ada yang sakit cepet ketahuan, kan WTS resiko

${ }^{25}$ Mawardi, (Pembina panti), Wawancara, Senin 13 Agustus 2018.

26 Sowinto, S.Sos, (Kasi Pembinaan Mental dan Kepribadian), Wawancara, 20 Oktober 2018.

${ }^{27}$ Ernal, S.St. (Kasi Pelayanan Kebutuhan dan Keperluan), Wawancara, 20 Oktober 2018.

28 Sabhana, Wawancara, 20 Oktober 2018. 
keserang penyakit kelaminnya lumayan besar." 29

"Manfaatnya bimbingan fisik banyak saya rasakan, saya terasa sehat, makannya teratur, bersih, jadi tau soal makanan bergizi." 30

\section{Bimbingan Mental}

Dalam kegiatan bimbingan mental terdiri dari: bimbingan kelompok, bimbingan perorangan. Materi yang disampaikan yaitu, pendidikan budi pekerti, serta pendidikan agama, Baca Tulis Alquran (BTA). Tujuannya adalah utuk membimbing dan memperbaiki mental atau psikologis para kelayan, meningkatkan semangat untuk tidak mudah menyerah oleh keadaan serta mampu mengangkat harkat dan martabat diri mereka sendiri kepada kehidupan yang lebih baik atau layak. Bimbingan mental ini dilatarbelakangi oleh permasalahan paling utama dan paling sulit untuk diperbaiki dalam diri Wanita Tuna Susila (WTS) berkaitan dengan kondisi mental. ${ }^{31}$

"Pembinaan mental porsinya lebih besar dan itu memang yang paling utama dari semua pembinaan atau bimbingan. Masalahnya, yang rusak dari WTS itu mentalnya, kalau mentalnya baik semiskin apapun dia, dia pasti tidak akan terjerumus ke dalam perbuatan tersebut. Bimbingan lainnya hanyalah pendukung dari bimbingan mental." 32

Mental kebanyakan Wanita Tuna Susila (WTS) terkondisi untuk memperoleh uang dengan mudah tanpa harus bekerja keras atau secara mudahnya mereka terbiasa untuk hidup malas. Mengingat akan hal itu maka bimbingan mental teramat penting peranannya dalam mengembalikan mereka ke arah yang benar.

\footnotetext{
${ }^{29} \mathrm{FY}$, W awancara, 20 Oktober 2018.

${ }^{30}$ MY, Wawancara, 20 Oktober 2018.

31 Mawardi, Wawancara, Senin 13 Agustus
}

2018.

32Sabhana, Wawancara, 20 Oktober 2018.
Secara nyata memang hasil dari bimbingan mental ini tidak mudah dilihat. Namun perubahan ini setidaknya dapat diamati dari cara mereka berpakaian, beribadah, berbicara dan bertingkah laku.

\section{Bimbingan Sosial Kemasyarakatan}

Bimbingan sosial kemasyarakatan adalah bimbingan yang bertujuan untuk mengarahkan kepada tata kerukunan dan kebersamaan hidup bermayarakat, sehingga dapat menimbulkan kesadaran tanggung jawab sosial, baik di lingkungan keluarga maupun masyarakat.

Materi pembinaan sosial meliputi materi pelajaran: kependudukan atau $\mathrm{KB}$, pendidikan kesadaran hukum, pengetahuan transmigrasi atau lingkungan hidup, hubungan antar manusia, bimbingan sosial pencegahan AIDS, pengetahuan PKK, kewiraswastaan dan kesenian. ${ }^{33}$

"Bimbingan sosial ini memberi manfaat bagi saya, disamping keterampilan. Disini saya mulai mengerti bahwa ternyata hidup menjadi manusia itu tidak seenaknya, banyak aturan yang mesti kita ikuti selama itu dalam kebaikan, tapi semua dapat membuat kita senang."

Untuk materi kesadaran hukum bertujuan menanamkan tanggung jawab dan kewajiban kelayan sebagai warga negara Indonesia. Melalui materi ini, mereka diberi pengetahuan dan pengertian tentang peraturan perundang-undangan yang telah mereka langgar sebagai Wanita Tuna Susila (WTS). Tidak hanya itu, melalui pendidikan kesadaran hukum juga diajarkan mengenai tugas, hak dan kewajiban sebagai bagian dari warga masyarakat dan warga negara. Harapan semua itu dapat menggugah kesadaran para kelayan untuk berpikir lebih luas dan jauh ke depan,

${ }^{33}$ Sabhana, Wawancara, Senin 13 Agustus 2018.

${ }^{34}$ EL, Wawancara, 20 Oktober 2018. 
tidak hanya untuk kepentingan sendiri tetapi juga untuk kepentingan orang lain.

\section{Bimbingan Keterampilan}

Dalam bidang keterampilan bimbingan yang diberikan meliputi menjahit atau tata busana, memasak atau tata boga, salon atau tata rias, dan keterampilan lainnya seperti menyulam kain batik, membordir, mandi lulur, dan rias penganten. Tujuan keterampilan ini agar mereka yang dibina memperoleh pengetahuan dan keterampilan sehingga mereka dapat membuka usaha sendiri dari keterampilan yang dimilikinya.

Keterampilan memasak yang diberikan adalah meliputi: praktek membuat putu ayu, tahu isi, agar-agar ubi, stick cumi-cumi, tahu telur, donat, tahu lapis, kue kukus ,bolu, roti tawar goreng, KFC, dan beragam macam masakan rumah lainnya. Keterampilan menjahit yang diberikan meliputi: pengetahuan dasar mesin dan cara memakai untuk menjahit, evaluasi dasar menjahit, pengambilan ukuran pakaian, macam-macam ukuran, menggambar pola dasar wanita, menggambar macammacam lengan dan kerah, menggambar pola rok, menggambar pola blus, menjahit rompi, dan lain-lain. ${ }^{35}$

"Sebenarnya sebelum saya masuk panti ini, saya sudah bisa sedikit cara menjahit, tapi masalah potong memotong pola dan bikinnya yang susah". ${ }^{36}$

"Sebelum ke sini saya belum bisa apaapa, makanya dulu saya jadi WTS, tapi sekarang saya sedikit-sedikit bisa bikin keterampilan. Bisa bikin bunga dari plastik, bikin figura, bikin tali rambut, terutama potong rambut dan rias muka. Saya pingin buka salon kecilkecilan setelah keluar dari sini." ${ }^{37}$

"Saya merasakan setelah disini saya sekarang bisa membuat bermacam-

\footnotetext{
35 Sabhana, Wawancara, Senin 13 Agustus 2018.

${ }^{36}$ EL, Wawancara, 20 Oktober 2018.

37 AA, Wawancara, 20 Oktober 2018.
}

macam kue, kalau sayur bening dari dulu juga bisa, tapi kalau kue kan masih bener baru buat saya. Niatnya setelah keluar dari sini saya pengin jualan aja, mudah-mudahan ada modalnya." 38

Pembina panti (Mawardi) juga mengungkapkan, bahwa kami menginginkan agar Wanita Tuna Susila (WTS) yang dibina di panti ini bisa membuka lapangan usaha setelah pulang atau keluar dari panti ini. Tujuannya agar mereka tidak lagi kembali kepada pekerjaan yang selama ini mereka lakukan yaitu menjadi Wanita Tuna Susila (WTS).

\section{KESIMPULAN}

Melalui penelitian yang dilakukan di panti Andam Dewi Solok yaitu berkaitan dengan pembinaan Wanita Tuna Susila (WTS) Sumatera Barata, peneliti dapat menyimpulkan sebagai berikut, ada beberapa hal yang menyebapkan mereka menjadi Wanita Tuna Susila (WTS) di antaranya: Saudari DS yang berusia 35 tahun. Dia ini merupakan penghuni di Andam Dewi Solok yang berasal dari Kota Padang. DS menjadi Wanita Tuna Susila (WTS) karena faktor ekonomi yang tidak mampu dia atasi. Masuknya DS ke dalam kehidupan Wanita Tuna Susila (WTS) berawal dari suaminya yang pergi tampa kabar dan sudah menikah lagi dengan wanita lain. Tuntutan ekonomi yang begitu berat yaitu, mesti menghidupkan 3 orang anak dan juga uang sekolahnya.

NA, yang biasa dipanggil . Dia yang berasal dari Kota Padang, menurut keterangannya, awal melakukan pekerjaan sebagai Wanita Tuna Susila (WTS) karena suka berhuru-hura bersama teman-teman, dan ada salah satu teman yang menawarkan pekerjaan tersebut dengan mengambarkan pendapatan yang bayak setiap malamnya. Awal

\footnotetext{
${ }^{38}$ FIT, Wawancara, 20 Oktober 2018.
} 
ditawarkan, saya menolak karena masih memikirkan orang tua. Tetapi teman saya terus mengajak dan merayu sehinga saya terpedaya.

WN, salah satu Wanita Tuna Susila (W'TS) yang berasal dari Pasaman Timur. Penyebab WN masuk ke panti Andam Dewi karena melakukan LGBT. Latar belakang Witriani sebagai pelaku LGBT karena pengaruh oleh pergaulan bebas yang sangat sulit dikontrolnya. Menurut wawancara yang dilakukan peneliti Witriani juga kurang perhatian dari kelurga, terutama orang tua.

Menurut wawancara di panti Andam Dewi, latar belakang NK menjadi Wanita Tuna Susila (WTS) karna masalah dalam keluarga dan ekonomi. Menurut keterangannya, awalnya saya sudah menikah dua kali, namun setiap pernikahan saya gagal.

AS adalah seorang Wanita Tuna Susila (WTS) yang mempunyai tiga orang anak. Dia memilih pekerjaan PSK karena tuntukan biaya kehidupan sehari-harinya. Dia telah ditinggalkan oleh suaminya dan harus memenuhi kebutuhan ketiga anaknya. Karena ekonomi jadi ia memilih pekerjaan tersebut.

PD menjadi Wanita Tuna Susila (WTS) karena permasalahan keluaga serta ekonomi. Menurut keterangannya, saya dimasukkan oleh salah seorang keluarga yang bekerja di panti Andam Dewi Solok, karena keluarga saya merasa kasihan dengan keadaan orang tua saya yang sering bertengkar dan tidak memperhatikan saya. Selain kurang kasih sayang dari orang tua ekonomi saya juga kurang cukupi. Oleh karena itu saya di bawa oleh keluarga dan di titipkan di panti Andam Andam Dewi.

PT melakukan pekerjaan menjadi Wanita Tuna Susila (WTS) karena pengaruh pergaulan bebas. Selain itu tergoda oleh pendapatan yang lumayan banyak setiap malamnya. HY terlibat dalam pergaulan bebas yaitu suka sesama jenis (LGBT) yang berasal dari Dumai. Menurut keterangannya, HY pernah menjalin hubungan dengan laki-laki, namun dia disakiti dan merasa trauma dan tidak percaya sama sekali kepada lelaki. Akibat faktor tersebut dia mulai menyukai sesama jenis dan terlibat dalam jaringan LGBT.

Ekonomi merupakan hal yang sangat penting dalam kehidupan, ekonomi bisa menjerumuskan manusia kedalam hal-hal yang tidak baik. Sama halnya seperti salah seorang Wanita Tuna Susila yang bernama MY. Menurut wawancara, karena faktor ekonomi saya mencoba-coba untuk melakukan pekerjaan tersebut, saya ditawarkan oleh teman dan mengambarkan mendapatkan uang yang banyak.

Dari berbagai latar belakang mereka menjadi Wanita Tuna Susila (WTS) di atas, peneliti menyimpulkan bahwa hal yang paling utama adalah faktor ekonomi. Perlu rasanya untuk kita semua untuk meningkatkan kreatifitas, pendidikan serta perhatian agar keluarga kita tidak terjerumus menjadi dalam hal yang dapat merusak masa depannya. Pembinaan yang dilakukan di panti Andam Dewi Solok, dapat dikelompokkan menjadi empat yaitu: bimbingan fisik, mental, sosial kemasyarakatan dan bimbingan keterampilan. 


\section{DAFTAR KEPUSTAKAAN}

AD/ART Panti Andam Dewi Solok, 1980.

Alfurqan, Alfurqan, Rini Rahman, and Muhamad Rezi. "Pendidikan Orang Dewasa Yang Dikembangkan Rasulullah." Islam Transformatif: Journal of Islamic Studies 1, no. 1 (August 7, 2017): 15-29. https://doi.org/10.30983/IT.V1I1.327.

Kartono, Kartini. Patologi Sosial. Bandung: CV Rajawali. 2011.

Laksana, Yuda Setia, Sholih Sholih, and Mochamad Naim. "Pelatihan Tata Rias Pengantin Bagi Wanita Tuna Susila Dalam Meningkatkan Kemandirian Usaha." Journal of Nonformal Education and Community Empowerment 1, no. 1 (June 30, 2017): 43-54. https://doi.org/10.15294/pls.v1i1.14794.

Ramadhani, Widya Suci, Sri Sulastri, and Soni Akhmad Nurhaqim. "Proses Rehabilitasi Sosial Wanita Tuna Susila di Balai Rehabilitasi Sosial Karya Wanita (BRSKW) Palimanan Kabupaten Cirebon.” Prosiding Penelitian Dan Pengabdian Kepada Masyarakat 4, no. 2 (July 31, 2017). https://doi.org/10.24198/jppm.v4i2.14292.

Simandjuntak. Pengantar Kriminal dan Patologi Sosial. Bandung: Tarsito. 1977.

\section{Wawancara}

Syahbana (Kepala Panti Andam Dewi Solok), Wawancara.

Mawardi (Pembina Panti Andam Dewi Solok), Wawancara.

DS (WTS) Wawancara.

NA, (WTS) Wawancara.

ARN, (WTS) Wawancara.

WT, (WTS) Wawancara.

NK, (WTS) Wawancara.

AS, (WTS) Wawancara.

PD, (WTS) Wawancara.

PA, (WTS) Wawancara.

HY, (WTS) Wawancara. 